\title{
Comparison of Physicochemical Properties of a Novel Polysaccharide Produced by Bacillus circulans with Commercial Polysaccharides
}

\author{
Yuka Isobe*, Yoko Toyama*, Mayumi Minamori*, Kumio YokolgawA*, \\ Kinji ENDO*, Fusako KAWAF* and Hiroyasu KAWAF \\ * Department of Food Science and Nutrition, Nara Women's University, \\ Kitauoya Nishimachi, Nara-shi, Nara 630 \\ ** Department of Biology, Kobe University of Commerce, Gakuen Nishimachi \\ 8-2-1, Nishiku, Kobe-shi, Hyogo 651-21
}

\begin{abstract}
Physicochemical properties of a new polysaccharide produced by Bacillus circulans were investigated by comparing with those of xanthan gum, locust bean gum, guar gum, sodium alginate and carboxymethylcellulose (CMC). The polysaccharide produced by $B$. circulans (BPS) showed a high water-holding capacity at $0.1 \%$ concentration together with a good emulsifying effect of oil next to xanthan gum. The viscosity of $1 \%$ BPS solution was about $900 \mathrm{cP}$, the value being nearly equal to that of xanthan gum. The viscosity of BPS solution was almost unchanged at a $\mathrm{pH}$ range between 5 and 9 , and the heat treatment of BPS at $100^{\circ} \mathrm{C}$ for $30 \mathrm{~min}$ brought about a $25 \%$ decrease in viscosity. The addition of $30 \%$ glucose to BPS solution enhanced the viscosity by $20 \%$, but the addition of $1 \%$ citric acid lowered the viscosity to about $30 \%$. A synergistic effect of BPS on the increase in the viscosity of locust bean gum or guar gum solution was observed. A maximum viscosity of a mixed solution of BPS and locust bean gum or guar gum was obtained at a ratio of about $2: 8(\mathrm{v} / \mathrm{v})$. A Young's modulus of a film prepared from BPS was apparently higher than that of CMC and guar gum.
\end{abstract}

Polysaccharides are present in plants and algae as natural constituents, and also as a product of microorganisms during growth ${ }^{1) 2}$. They are useful as raw materials in food and non-food industry because of their physical characteristics. Some of the polysaccharides originated from plants and microorganisms are used as a thickener and stabilizer of food, edible films, and an additive for a water-holding reagent and stabilizer of non-food materials, etc ${ }^{3)}$. Unlike synthetic polymers, these biopolymers do not cause environmental pollution as they are easily decomposed by microorganisms in natural environment. Especially, polysaccharides produced by microorganisms are paid much attention due to their characteristics and availability to applied fields as compared with polysaccharides derived from plants ${ }^{(4) \sim 6)}$.

In our previous papers, we reported that a soil bacterium Bacillus circulans produced a highly viscous polysaccharide consisting of L-rhamnose, D-galactose, D-mannose, and mannuronic acid or glucuronic acid as sugar components in a medium containing glucose as

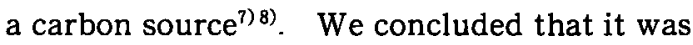
a novel bacterial polysaccharide from its chemical composition, and the chemical structure of the polysaccharide is now under investigation.

In this report, we investigated some physicochemical properties of the polysaccharide produced by $B$. circulans (BPS) to examine the possibility of its application to food and non-food industry as raw materials. We chose five kinds of polysaccharide from various sources which have different physical properties according to their chemical structures, and compared their properties with those of BPS. 


\section{Materials and Methods}

\section{Materials}

Xanthan gum from bacteria (Xanthomonas campestris), locust bean gum (Ceratania siliqua) and guar gum (Cyamopsis tetragonolobus) from plants, sodium alginate from brown algae and carboxymethylcellulose were used in this study. Guar gum, locust bean gum and xanthan gum ( $\mathrm{K}$ and $\mathrm{Na}$ form) were kindly supplied by Dainippon Pharmaceutical Co. Ltd., Osaka. Sodium alginate, carboxy methylcellulose and other chemicals were purchased from Nacalai Tesque Inc., Osaka. Locust bean gum was dissolved in distilled water by stirring at $80^{\circ} \mathrm{C}$ for $15 \mathrm{~min}$, and other polysaccharides were dissolved at room temperature before use.

Culture conditions of bacteria for polysaccharide production

A polysaccharide-producing bacteria Bacillus circulans was used in this study ${ }^{7}$. A culture medium of the bacteria for polysaccharide production contained $1 \%$ glucose, $0.05 \%$ asparagine, $0.005 \%$ yeast extract, $0.05 \% \mathrm{KH}_{2}-$ $\mathrm{PO}_{4}, 0.005 \% \mathrm{MgSO}_{4} \cdot 7 \mathrm{H}_{2} \mathrm{O}, 0.005 \% \mathrm{CaCl}_{2} \cdot 2 \mathrm{H}_{2} \mathrm{O}$, $0.005 \% \mathrm{ZnSO}_{4} \cdot 7 \mathrm{H}_{2} \mathrm{O}$ and $0.005 \% \mathrm{FeCl}_{3} \cdot 6 \mathrm{H}_{2} \mathrm{O}$. The $\mathrm{pH}$ of the medium was adjusted to 7.0 before autoclaving at $120^{\circ} \mathrm{C}$ for $15 \mathrm{~min}$. A jar-fermentor (MSJ-30, Marubishi B.E. Co., Ltd.) culture was done at $30^{\circ} \mathrm{C}$ for $48 \mathrm{hr}$ with $10 \mathrm{l}$ of the medium by inoculating $1 l$ of a preculture, which was cultured as described in the previous paper ${ }^{8)}$, with an aeration rate at $1.5 l$ per min and an agitation speed at $300 \mathrm{rpm}$.

Isolation and purification of polysaccharide

A culture fluid obtained by jar-fermentor was diluted with an equal volume of water and centrifuged at $10^{\circ} \mathrm{C}$ for $20 \mathrm{~min}$ at $18000 \times \mathrm{g}$ to remove bacterial cells. To the supernatant solution, $1 \%$ cetyltrimethylammoniumbromide solution was added until no more precipitate of polysaccharide-detergent complex occurred. The precipitate was collected by filtration, washed with water, and dissolved in $10 \%$ sodium chloride solution by stirring. Two volumes of ethanol were added to the solution, and the resulting precipitate was collected by centrifugation at $3000 \times \mathrm{g}$ for $10 \mathrm{~min}$, dissolved in distilled water and dialyzed overnight against distilled water at $4^{\circ} \mathrm{C}$. The dialyzed solution was lyophilized, and the lyophilized preparation was used for examinations.

\section{Measurement of water-holding capacity}

A water-holding capacity of each polysaccharide preparation was measured as follows. A tip of a filter paper (Toyo Roshi No. 51, $2 \times 40$ $\mathrm{cm}$ ) was dipped in $0.1,0.5$ and $1 \%$ polysaccharide solutions and kept for $1 \mathrm{hr}$ at room temperature. A moving distance of water from a starting line was measured and a water-holding capacity of polysaccharide solution was expressed as a relative value of moving distance of water to that of distilled water ${ }^{9)}$

Measurement of stability of emulsion

Each polysaccharide solution $(5 \mathrm{ml})$ and salad oil ( $5 \mathrm{~m} l$, Nisshin Oil Co., Ltd.) were mixed and homogenized with an Ultra-disperser (LK21 , Yamato) for $2 \mathrm{~min}$ in a $20 \mathrm{ml}$-graduated test tube. The mixture was kept for 7 days at room temperature and the stability of emulsion was evaluated by measuring the volume of three layers of emulsion, water and oil ${ }^{10)}{ }^{11}$.

Measurement of viscosity

The viscosity of polysaccharide solution was measured by a B $8 \mathrm{M}$ rotation viscometer (Tokimek) with a HM-1 rotor at $12 \mathrm{rpm}$ (shear rate : $15.8 \mathrm{sec}^{-1}$ ) at $25^{\circ} \mathrm{C}$ unless otherwise stated.

Measurement of Young's modulus of films prepared from polysaccharide

A film of polysaccharide was prepared as follows ; $50 \mathrm{ml}$ of $1 \%$ polysaccharide solution was poured into an acrylic plate $(15 \times 15 \times 0.5$ $\mathrm{cm}$ ) set at level, and dried in a desiccator with silica gel at room temperature. Prepared films were left at room temperature $\left(20+0.5^{\circ} \mathrm{C}, 60+\right.$ $2 \% \mathrm{RH}$ ) for more than $24 \mathrm{hr}$. The extension test of films $(0.5 \times 5 \mathrm{~cm})$ was performed with a tensile tester (KES-G1, Kato Tech. Co., Ltd.). Young's modulus was calculated from the slope of the stress-strain curve at a constant rate of extension strain $(0.002 \% / \mathrm{sec})$. The thickness of films was measured at five points on each film $(0.5 \times 5 \mathrm{~cm})$ by a compression tester (KES-FB3, Kato Tech. Co., Ltd.) and a mean value was used for calculation. 


\section{Results and Discussions}

Water-holding capacity of polysaccharide

A water-holding capacity of BPS was compared with some polysaccharide preparations available at the market. As shown in Fig. 1, the BPS solution showed the lowest moving rate of water among the polysaccharides tested at the range from 0.1 to $1.0 \%$ concentration, the result indicated that BPS had the highest water-holding capacity among the polysaccharides tested.

\section{Stability of emulsion}

Highly viscous polysaccharides are often used as an emulsifier in food-manufacturing industry, for example, xanthan gum is known to be a good stabilizer of emulsion ${ }^{12)}$. Then the effect of BPS on the stabilization of emulsion with oil and water was compared with that of other polysaccharides. As shown in Fig. 2, 1\% BPS had a maximum effect on the stabilization of emulsion. Xanthan gum was effective at a concentration of $0.5 \%$ to give a

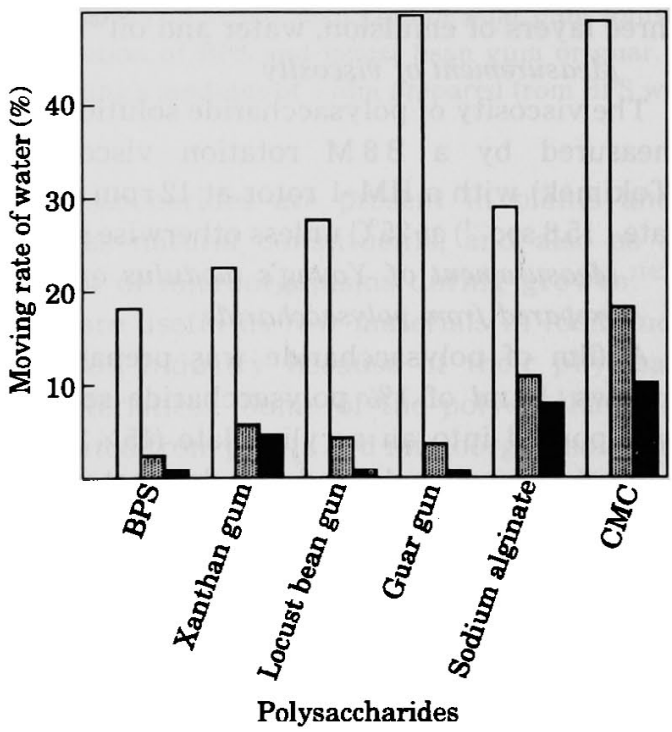

Fig. 1 Water-holding capacity of various polysaccharides

Concentration of polysaccharide $0.1 \%$

$0.5 \% ; \quad 1.0 \%$

BPS : Polysaccharide produced by Bacillus circulans

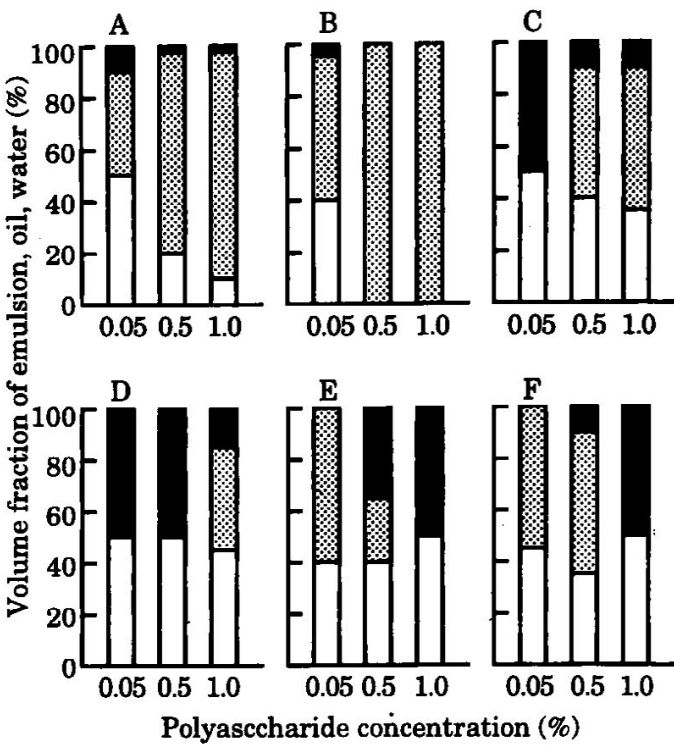

Fig. 2 Comparison of stability of emulsion $\square$, water; emulsion; $\square$, oil

A, BPS ; B, Xanthan gum ; C, Guar gum ; D. Locust bean gum;E, Sodium alginate; F, CMC

complete stabilization. From these results, BPS is effective next to xanthan gum, but more than $1 \%$ BPS seems to be required as an emulsion stabilizer.

The effect of addition of sodium chloride or acetic acid to BPS solution on the stability of emulsion was examined. The addition of sodium chloride $(2.5 \%)$ lowered the stability of emulsion slightly, but acetic acid had no effect on the stability at a final concentration of $10 \%$ (data not shown). As the pH of BPS solution containing $10 \%$ acetic acid was 2.5 , BPS seemed to have a stabilizing effect of emulsion at acidic $\mathrm{pH}$ ranges.

\section{Rheological properties of polysaccharides \\ 1) Polysaccharide concentration and viscos- ity}

The relationship between the concentration of polysaccharides and viscosity of their solution is shown in Fig. 3. The viscosity of BPS solution was increased logarithmically with increasing concentration from $0.1 \%$ to $1.0 \% ; 150$ $\mathrm{cP}$ for $0.5 \%$ solution and about $900 \mathrm{cP}$ for $1.0 \%$ solution, respectively. A linear change of vis- 


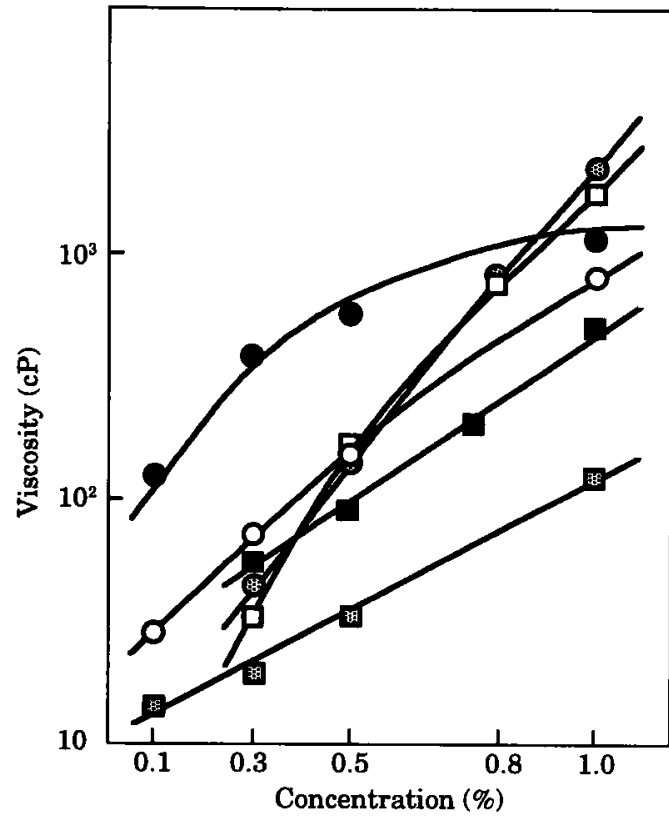

Fig. 3 Viscosity change with concentration of polysaccharide

O. BPS ; Xanthan gum ; . Locust bean gum ; $\square$. Guar gum ; $\square$, Sodium alginate ; $:$ CMC

Rotor : HM-1 at $3 \mathrm{rpm}$, viscosity : $10^{3} \mathrm{cP}>$, shear rate : $4 \mathrm{sec}^{-1}$

$\mathrm{HM}-2$ at $12 \mathrm{rpm}$, viscosity : $10^{3} \mathrm{cP}<$, shear rate : $4 \mathrm{sec}^{-1}$

cosity was also observed in locust bean gum, guar gum, sodium alginate and $\mathrm{CMC}$, while xanthan gum was relatively highly viscous at lower concentration than other polysaccharides and the viscosity increased slowly over $0.5 \%$ concentration. The viscosity of BPS solution was as high as that of these commercial polysaccharides. A detailed flow behavior of BPS is now under investigation.

2) Effect of $p H$ on viscosity

The effect of $\mathrm{pH}$ on the viscosity of polysaccharide solution was investigated. The $\mathrm{pH}$ of each polysaccharide solution (viscosity of each solution was set at $125 \mathrm{cP}$ ) was adjusted to 2 to 11 with $0.1 \mathrm{~N} \mathrm{HCl}$ or $0.1 \mathrm{~N} \mathrm{NaOH}$. As shown in Fig. 4, the viscosity of BPS solution was nearly independent at the $\mathrm{pH}$ range between 5.0 and 9.0 , but it decreased rapidly by shifting the $\mathrm{pH}$

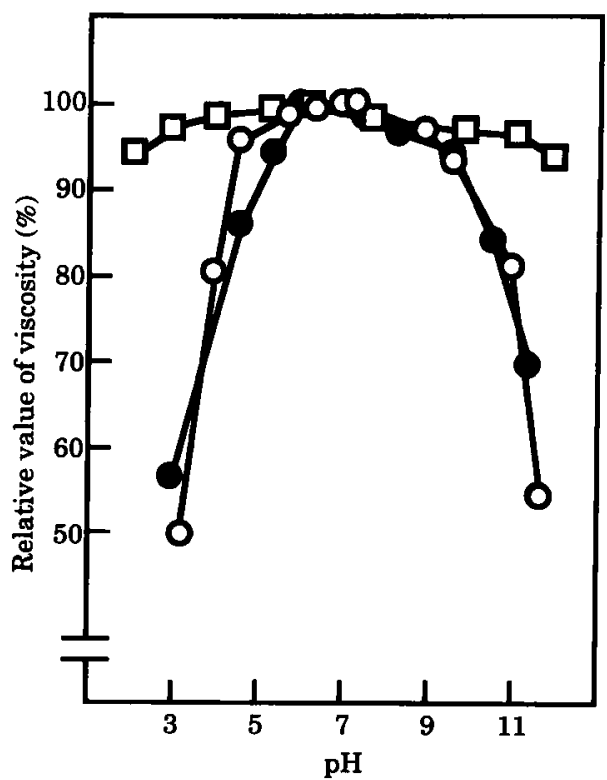

Fig. 4 Effect of $\mathrm{pH}$ on viscosity

O. BPS $(0.40 \%)$; Xanthan gum $(0.22 \%)$;

Guar gum (0.45\%)

The viscosity of polysaccharide solution before adjusting of $\mathrm{pH}$ was expressed as $100 \%$.

to acidic or alkaline side. A similar tendency of viscosity change was observed for xanthan gum, CMC and sodium alginate (data not shown). As these polysaccharides have carboxyl residues, the change of viscosity with $\mathrm{pH}$ may be due to the alteration of molecular conformation led by the change of a net charge of polysaccharide molecule. This assumption was confirmed by the result that the viscosity was recovered when the $\mathrm{pH}$ of polysaccharide solutions with low viscosity was readjusted to $5-9$. On the other hand, the viscosity of locust bean gum and guar gum, which are mainly composed of galactomannan, was not affected by the change of $\mathrm{pH}$. This may be due to their neutral molecular structure.

3) Effect of heating temperature on viscosity

The change of viscosity was examined by heating each polysaccharide solution at $100^{\circ} \mathrm{C}$ for 5-30 min. As shown in Fig. 5, the viscosity of BPS was apparently decreased with heating time. BPS was unstable to heating next to 


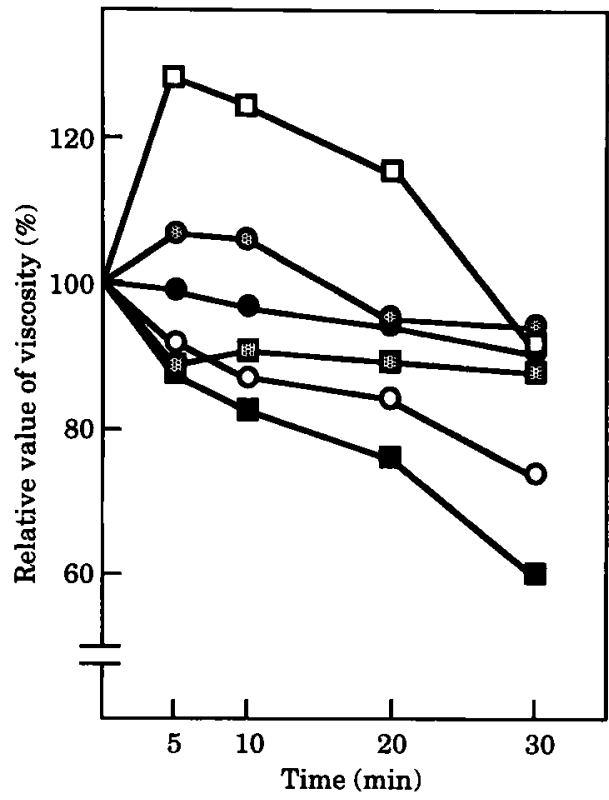

Fig. 5 Effect of heating time on viscosity of various polysaccharides

O. BPS $(0.40 \%)$; Xanthan gum $(0.22 \%)$; 중, Locust bean gum $(0.48 \%) ; \square$, Guar gum $(0.45 \%) ; \square$, Sodium alginate $(0.57 \%) ; 8, \mathrm{CMC}$ (1.0\%)

The viscosity of polysaccharide solution without heating was expressed as $100 \%$.

sodium alginate. Little change in the viscosity of these heat-treated BPS solutions was observed after they were kept at $8^{\circ} \mathrm{C}$ for $24 \mathrm{hr}$, indicating that an irreversible change of molecular conformation of BPS had occurred by the heating. However, BPS solution seems to be stable by heating at $80^{\circ} \mathrm{C}$ for $30 \mathrm{~min}$ (data not shown). The viscosity of guar gum and locust bean gum was increased with heating at $100^{\circ} \mathrm{C}$ for 5-10 min. This result indicates that the effect of heating may depend on the structural difference of polysaccharide. The increase in the viscosity of neutral polysaccharide (guar gum and locust bean gum) may be due to the progress of hydration by cooling the heated solution.

4) Effect of addition of sugar on viscosity

The effects of addition of glucose on the viscosity of polysaccharide solutions were in- vestigated. As shown in Fig. 6, the viscosity of BPS, sodium alginate and CMC was increased by adding increasing amount of glucose. A similar effect was also observed when sucrose or fructose was added to the polysaccharide solution (data not shown).

As the viscosity of these sugar solutions was negligible even at the concentration of $30 \%$, the increase in the viscosity by the addition of these sugars may be attributable to the change of conformation of polysaccharide by interaction with added sugar molecules.

5) Effect of addition of organic acid on viscosity

The effect of addition of citric acid on the viscosity of BPS, xanthan gum, locust bean gum and CMC are shown in Fig. 7. The viscosity of BPS solution in the presence of $1 \%$ citric acid was decreased to about $30 \%$ of that without acid, while that of xanthan gum was about $60 \%$ by adding the same amount of citric acid. CMC was less affected in the presence of citric acid. It seems that the viscosity change

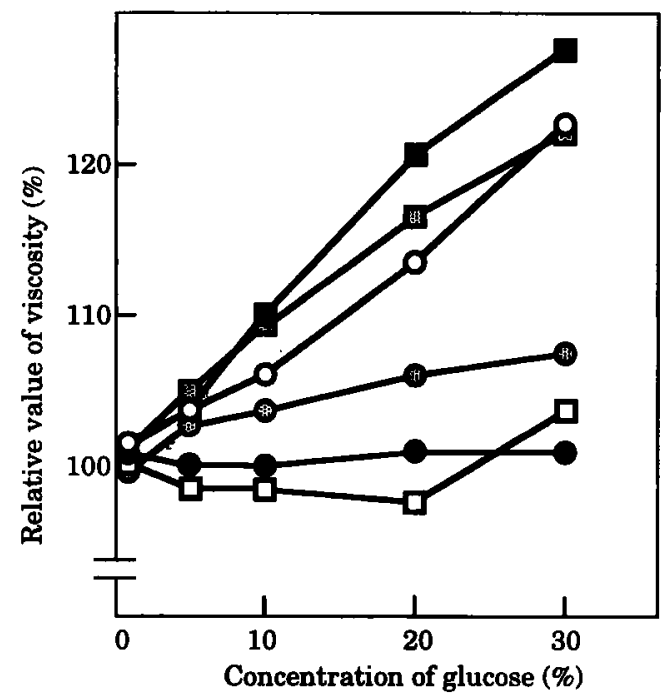

Fig. 6 Effect of glucose on viscosity

○. BPS $(0.40 \%)$; Xanthan gum (0.22\%) ; Locust bean gum $(0.48 \%) ; \square$, Guar gum $(0.45 \%)$; $\square$. Sodium alginate $(0.57 \%)$; 8 , CMC (1.0\%)

The viscosity of polysaccharide solution without glucose was expressed as $100 \%$. 


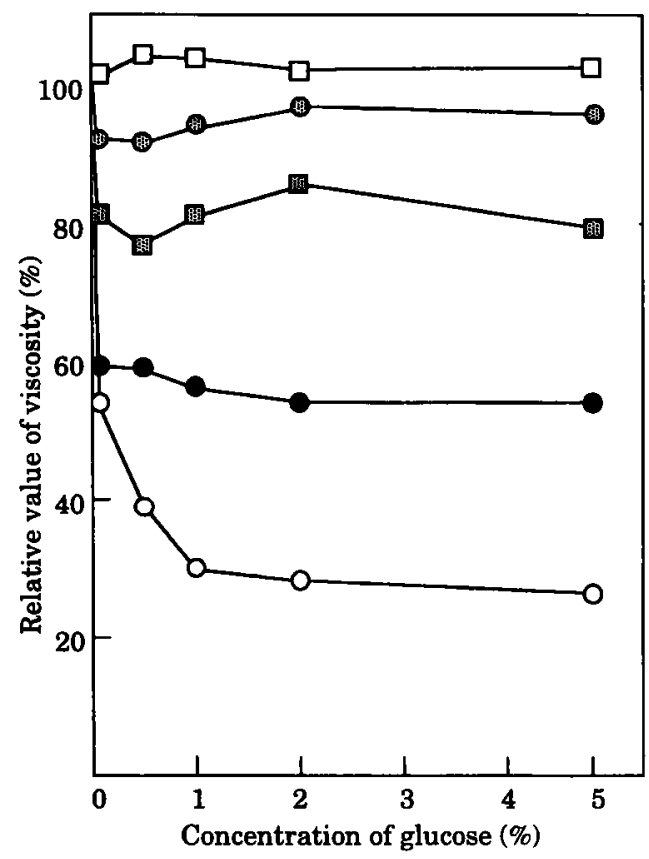

Fig. 7 Effect of citric acid on viscosity

O, BPS $(0.40 \%)$; Xanthan gum $(0.22 \%)$; Locust bean gum $(0.48 \%) ; \square$, Guar gum $(0.45 \%)$; $2 \mathrm{CMC}(1.0 \%)$

The viscosity of polysaccharide solution without citric acid was expressed as $100 \%$.

of these three acidic polysaccharides may be related to the decrease of $\mathrm{pH}$ by addition of citric acid. On the other hand, the viscosity of guar gum and locust bean gum did not change by the addition of citric acid. A similar tendency was also found for these polysaccharides by adding succinic and lactic acid (data not shown). The viscosity of sodium alginate $(0.57 \%)$ was increased by the addition of $1-2 \%$ citric acid, and a gel formation was observed by addition of more than $5 \%$ of the acid (data not shown).

\section{6) Synergistic effect of BPS on viscosity of other polysaccharides}

It is well known that a solution of xanthan gum forms a gel when it is mixed with locust bean gum, and that the viscosity of xanthan gum solution increases when it is mixed with guar gum $^{13)}$. As BPS is an acidic polysaccharide similar to xanthan gum from bacteria, the effect of addition of BPS on the viscosity of locust bean gum or guar gum was investigated. A solution of locust bean gum or guar gum (each $0.5 \%$ ) was mixed with $0.5 \%$ BPS solution at different ratio, and the viscosity of the mixture was measured. As shown in Fig. 8, the viscosity of a mixed solution of BPS with locust bean gum or BPS with guar gum reached a maximum at the ratio of about $2: 8$ $(\mathrm{v} / \mathrm{v})$. It seems from these results that BPS has a synergistic effect to increase the viscosity of locust bean gum or guar gum solution, though the effect was slightly smaller than xanthan gum (data not shown). It is assumed that synergistic effect of xanthan gum on locust bean gum or guar gum results from their similarity of structure with the backbone of $\beta$ 1, 4 linkage of sugar components. Since BPS showed less synergistic effect than xanthan gum, BPS may have a different backbone structure from locust bean gum and guar gum. The synergistic effect of BPS on locust bean gum or guar gum may be due to the entanglement of molecular chain to form dense network structures. In other experiment, we examined synergistic effect of BPS on viscosity

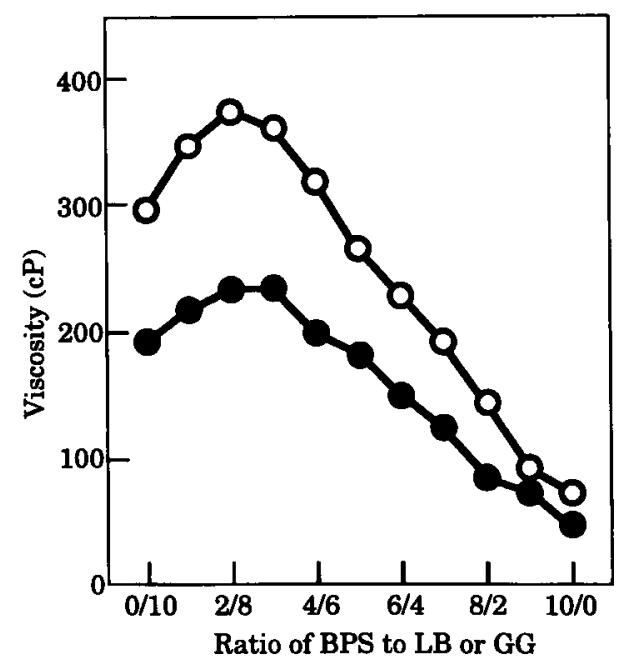

Fig. 8 Synergism of BPS and other polysaccharides on viscosity

Concentration of polysaccharide : $0.5 \%$

O. LB (locust bean gum) ;, $\mathrm{GG}$ (guar gum)

Rotor : HM-2 at $30 \mathrm{rpm}$, shear rate : $10.2 \mathrm{sec}^{-1}$ 


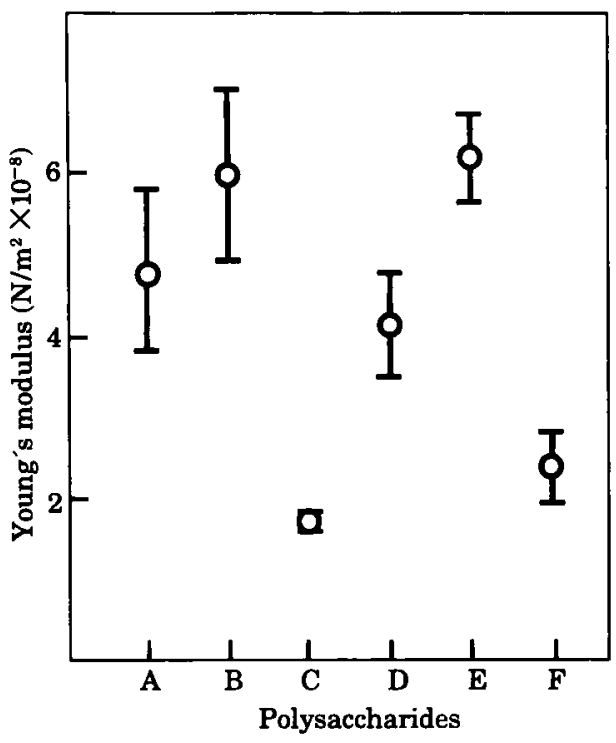

Fig. 9 Young's modulus of films made from various polysaccharides

A, BPS $(n=6) ; B$, Xanthan gum $(n=3) ; C$, Guar gum $(n=10) ; D$, Locust bean gum $(n=$ 6) ; $\mathrm{E}$, Sodium alginate $(\mathrm{n}=9)$; F, CMC $(\mathrm{n}=12)$ Data was shown by mean values \pm S.E. Coefficient of variation of film thickness: BPS (39\%), Xanthan gum (25\%), Guar gum (18\%), Locust bean gum (23\%), Sodium alginate $(28 \%), \mathrm{CMC}(37 \%)$

of xanthan gum. The viscosity of mixed solutions (BPS and xanthan gum) apparently increased as compared with the case of individual solutions (data not shown).

7) Young's modulus of polysaccharide films

Some of the bacterial polysaccharides are used for the preparation of edible films. Therefore, we compared the ability of film formation of BPS with other polysaccharides. All the polysaccharides examined had the ability of film formation. The average of thickness of films were as follows : BPS $(80 \mu \mathrm{m})$, xanthan gum $(100 \mu \mathrm{m})$, guar gum $(350 \mu \mathrm{m})$, locust bean $\operatorname{gum}(160 \mu \mathrm{m})$, sodium alginate $(50 \mu$ $\mathrm{m}), \mathrm{CMC}(70 \mu \mathrm{m})$. Stress and strain of films $(0.5$ $\times 5 \mathrm{~cm}$ ) were measured and Young's modulus was determined. As shown in Fig. 9, the Young's modulus of these films was in the order of $10^{8} \mathrm{~N} / \mathrm{m}^{2}$. The Young's modulus of
BPS film was $5 \times 10^{8} \mathrm{~N} / \mathrm{m}^{2}$, which was higher than that of $\mathrm{CMC}$ and guar gum $(\mathrm{P}<0.05)$. The results indicate that BPS is available to film formation as other polysaccharides.

\section{Acknowledgements}

The authors wish to thank Professor M. NiwA of the Department of Textile and Apparel Science, Nara Women's University, for her kind advice on the analysis of physicochemical properties of films made from polysaccharides.

\section{References}

1) HaRAdA, T. : Hakko to Kogyo, 36, 2 (1977).

2) HAMADA, N. : Kagaku to Kogyo, 55, 92 (1981).

3) Hamada, N. : Kagaku to Kogyo, 55, 133 (1981).

4) Harada, T. : Koubunshi, 33, 374 (1984).

5) WEINER, R.M., COLWELl, R.R., JARMAN, R.N., Stein, D.C., Somerville, C.C. and Bonar, D.B. : Biotechnology, 3, 899 (1985).

6) Sandford, P.A., Cottrell, I.W. and Pettitt, D. J. : Pure Appl. Chem., 56, 879 (1984).

7) Isobe, Y., Endo, K. and KAWAI, H.: Biosci. Biotech. Biochem., 56, 636 (1992).

8) KaWAI, H., Isobe, Y., HoRIBE, M., ToKudA, J., ToKuno, I., ENDO, K. and KAWAI, F.: Biosci. Biotech. Biochem., 56, 853 (1992).

9) Ninomiya, E., KıZAKI, T. and HaNAdA, K. : Nippon Shokuhin Kogyo Gakkaishi, 14, 438 (1967).

10) Kawaguchi, K., Amano, T., Satomi, $K$, Yokoyama, M. and Kadota, G. : Nippon Suisan Gakkaishi, 54, 1817 (1988).

11) SANO, M : Chorikagaku, 15, 139 (1982).

12) NAKAYAMA, K. and KANEKo, K. : Shokuhinkogyo, 31, 47 (1988).

13) Dea, I.C.M., MorRIS, E.R., Rees, D.A., Welch, E. J., BEnEs, H.A. and PrICE, J : Carbohydr. Res., 57, 249 (1977).

(Received Aug. 29, 1994)

\section{Bacillus circulans が生産する新規多糖と 市販多楁類の物理化学的性留の比}

磯部由香* · 戸山陽子*・皆森真由美*・横井川久己男* 遠藤金次 $*$ 河合富佐子"* 河合弘康"

*奈良女子大学生活環境学部食物科学講座 （下630 奈良市北魚屋西町）

**神戸商科大学一般教育学科生物学教室 （干651-21 兵庫県神戸市西区学園西町 8-2-1） 
Bacillus circulans の生産する高粘性多糖 (BPS) の物 理化学的性質を、キサンタンガム、ローカストビーンガ ム、グアガム、アルギン酸ナトリゥムおよびカルボキシ メチルセルロース (CMC) のそれらと比較検討した. BPS は比較したどの多糖類よりも保水性に優れ，乳化 安定性もキサンタンガムについで優れていた.

$1.0 \% \mathrm{BPS}$ 水溶液の粘度は約 $900 \mathrm{cP}$ で, 他の高粘性多 糖と同程度もしくはそれ以上の粘性を示した。
BPS 水溶液の粘性は $\mathrm{pH}$ 5 9でほ上んど変化が見ら れず, $80^{\circ} \mathrm{C}$ までの加熱には比較的安定であった. また, グルコースの添加により粘度は增大し，クエン酸の添加 により粘度が減少した．ローカストビーンガムやグアガ ムなどのガラクトマンナン系の多糖と BPS との併用に より增粘効果がみられた。

BPS はフィルム形成能を持ち，作成したフィルムのヤ ング率は CMCやグアガムのフィルムよりも危険率 $5 \%$ 以下で有為に高かった. 